\title{
SPORTUOJANČIŲ VAIKŲ IR PAAUGLIŲ ŠIRDIES IR KRAUJAGYSLIŲ SISTEMOS FUNKCINIAI YPATUMAI
}

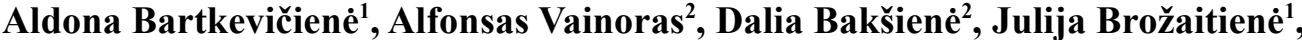 \\ Nijolẻ Raškauskienè ${ }^{1}$, Sigita Kibildiené ${ }^{3}$, Nadežda Rožnova ${ }^{4}$ \\ Kauno medicinos universiteto Psichofiziologijos ir reabilitacijos institutas, Palanga ${ }^{I}$, \\ Kauno medicinos universitetas, Kaunas ${ }^{2}$, Klaipedos sporto medicinos centras, Klaipeda ${ }^{3}$, \\ Klaipédos vaiku ligonine, Klaipéda ${ }^{4}$, Lietuva
}

\begin{abstract}
Aldona Bartkevičienė. Kauno medicinos universiteto Psichofiziologijos ir reabilitacijos instituto jaunesnioji mokslo darbuotoja. Moksliniu tyrimų kryptis - sportuojančio vaiko ir paauglio kairiojo skilvelio morfometrinių parametrų, funkcijos bei širdies ir kraujagyslių sistemos funkcinių rodikliu ypatumai.
\end{abstract}

\section{SANTRAUKA}

Iki šiol nepakanka tyrimu, nagrinejjančiu sportuojančiu vaiku ir paaugliu širdies ir kraujagysliu sistemos (ŠKS) adaptacija prie fizinio krūvio. Šio tyrimo tikslas - naudojantis žmogaus organizmo funkcinès būklès ìvertinimo modeliu, išnagrinèti sportuojančiu 12-17 metu vaiku ir paaugliu širdies ir kraujagysliu sistemos funkciniu rodikliu kitimo greiti dozuoto fizinio krūvio metu.

Buvo ištirti 160 krepšinio, dviračiu, irklavimo sporto šakas kultivuojančiu 12-17 metu berniuku. Kontrolinę tiriamuju grupę sudare 79 sveiki nesportuojantys to paties amžiaus, lyties vaikai ir paaugliai.

Atlikta visu tiriamuju $M$ režimo ir dvimatè echokardiografija. Diastolès metu išmatavus tarpskilvelinès pertvaros (TSPd), KS užpakalinès sienelès stori (KSUSd) ir kairiojo skilvelio diastolini skersmeni (KSDd), apskaičiuota KS miokardo masè (KSMM). Visi tiriamieji atliko veloergometrini mégini. Tirti šie rodikliai ir ju kitimo greitis: širdies susitraukimo dažnis (ŠSD), R-R intervalas (RR), J-T intervalas (JT), sistolinis arterinis kraujospüdis (S), diastolinis arterinis kraujospūdis (D), pulsinè amplitudè (S-D) ir išvestinis dydis - santykine repoliarizacija JT / RR.

Tyrimas parodè, kad sportuojančiu tiriamuju ŠSD kitimo greitis per visas krūvio pakopas statistiškai reikšmingai skyrèsi nuo nesportuojančiu kontrolinès grupés tiriamuju $(p<0,05)$. Per paskutinę krūvio pakopa (esant rezerviniu galimybiu mobilizacijos stadijai) maksimaliai pakito tiriamuju $\check{S} S D$, JT, JT/RR, S, (S-D) kitimo greitis. Irkluotoju ŚSD kitimo greitis mažiausias aštunta, krepšininku ir dviratininku — dešimta, kontrolinès grupés tiriamuju — šešta fizinio krūvio minutę. Kontrolinès grupès tiriamuju JT kitimo greitis padidejo šešta krūvio minutę ir skyrési nuo krepšininku, irkluotoju ir dviratininku ( $<<0,05)$, nuo šeštos iki aštuntos minutès mažèjo tolygiai. Sportuojančiu tiriamuju JT / RR kitimo greitis buvo mažiausias aštunta krūvio minute (skirtumas tarp dviratininku ir kontrolinès grupès $-p<0,05$ ), o kontrolinès grupés tiriamuju - šešta minutę (skirtumas tarp krepšininku ir kontrolinès grupés - $p<0,05$ ). Krepšininku $S$, (S-D) kitimo greitis mažiausias aštunta minutę (skirtumas tarp krepšininku ir kontrolinès grupés - $p<0,05$ ), irkluotoju ir dviratininku — dešimta minutę, o kontrolinès grupés tiriamuju — šešta minutę (skirtumas tarp krepšininku, irkluotoju, dviratininku ir kontrolinès grupes - p <0,05). Pasiekus mažiausia $\breve{S} S D$, JT / RR, S, (S-D) kitimo greičio amplitudę, per paskutinę krūvio pakopq sportuojančiu ir nesportuojančiu tiriamuju grupése šiu rodikliu kitimo greitis vèl padidèjo. Didesnè JT / RR kitimo greičio amplitudès kaita pastebèta tarp krepšininku, lyginant su irkluotojais, dviratininkais ir kontrolinès grupès tiriamaisiais. Fizinio krūvio pradžioje tarp sportuojančiu tiriamuju kairiojo skilvelio miokardo masès (KSMM) ir ŠSD kitimo greičio buvo nustatytas neigiamas koreliacinis ryšys $(r=-0,3)$, kuris stiprejo didinant fizini krūvi (dešimta minutę $r=-0,5)$.

Apibendrinant šio tyrimo rezultatus galima teigti, kad sportuojantys vaikai ir paaugliai rezerviniu galimybiu mobilizacijos stadija (maksimalu ŠSD, JT/RR, S, (S-D) greičio pokyti) pasiekia vèliau, lyginant su kontrolinès grupès tiriamaisiais. Tai gali rodyti geresnę vaiku širdies ir kraujagysliu sistemos adaptacija prie fizinio krūvio, lyginant su nesportuojančiaisiais, tačiau maksimalaus intensyvaus fizinio krūvio metu gali būti viršijamos širdies ir kraujagysliu sistemos funkcinès galimybès.

Raktažodžiai: širdies ir kraujagysliu sistema, funkciniu rodikliu kitimo greitis, kairiojo skilvelio miokardo masé.

\section{IVADAS}

$\mathrm{M}$ okslinèje literatūroje nestokojama duomenų apie suaugusių sportininkų širdies ir kraujagysliu sistemos ( ̌́KS) adaptaciją prie fizinio krūvio (Spirito et al., 1994; Sharma, 2003), o apie vaikų ir paauglių fizinio krūvio poveiki jų ŠKS žinoma gerokai mažiau, nors sportuojančių vaikų daugeja (Triposkiadis et al., 2002; Vasiliauskas et al., 2006). Vaikui augant, jo ŠKS nuolatos kinta: didèja širdies svoris, tūris, kinta jos struktūra, vystosi organizmo fiziologinès funkcijos ir nusistovi tam tikri ryšiai tarp atskiru organizmo funkcinių sistemų (Lodish et al., 2000). 
Sportuojančiu vaikų ir paauglių ŠKS veikia ne tik fizinis krūvis, bet ir organizmo augimas ir brendimas (Amstrong, Welsman, 2005).

Lietuvoje pradèta domètis suaugusiu sportininku organizmo sistemine adaptacija prie fizinio krūvio (Vainoras, 1996; Žumbakyte, 2007). Visgi tiek Lietuvos, tiek pasaulinejje mokslinejje literatūroje nepakanka mokslinių tyrimų, nagrinėjančių sportuojančių vaiku ir paauglių ŠKS funkcinę būklę, sisteminę organizmo reakciją i fizini krūvị. ŠKS funkcinès galimybès dažnai tampa veiksniu, ribojančiu organizmo adaptaciją prie fizinio krūvio. Intensyvaus ir nuolatinio fizinio krūvio metu gali būti viršijamos vaikų ir paauglių organizmo fiziologiniu galimybių ribos, todèl gali kilti grèsmé sveikatai ir gyvybei. Taigi svarbu ivertinti sportuojančių vaikų ir paauglių ŠKS ilgalaikę adaptaciją prie fizinio krūvio.

Tyrimo tikslas - naudojantis žmogaus organizmo funkcinès būklès įvertinimo modeliu išnagrinèti sportuojančiu $12-17$ metu vaikų ir paauglių ŠKS funkcinių rodiklių kitimo greiti dozuoto fizinio krūvio metu.

\section{TYRIMO METODIKA IR ORGANIZAVIMAS}

Tyrimas atliktas gavus Kauno regioninio biomedicininių tyrimu etikos komiteto leidimą (protokolo Nr.151/2007). Tiriamieji ir jų tèvai buvo informuoti apie tyrimą, jo tikslus. Sutikę dalyvauti tiriamieji ir jų tèvai užpildè asmens sutikimo formą ir pasirašè.

Buvo tiriama 160 atsitiktinai atrinktu $12-17$ metų berniukų, kultivuojančių tris sporto šakas: krepšini, dviračiu sportą ir irklavimą.

Kontrolinę grupę sudare to paties amžiaus ir lyties 79 sveiki nesportuojantys vaikai ir paaugliai. Tiriamieji buvo suskirstyti $\mathfrak{i}$ keturias grupes: nesportuojantys, kultivuojantys irklavimo sporto šaką (irkluotojai), krepšini (krepšininkai), dviračių sportą (dviratininkai). Tiriamujų charakteristika pateikta 1 lentelèje.

Tiriamieji buvo pasverti naudojant medicinines svarstykles ir pamatuotas jų ūgis. Korotkovo metodu kairès rankos žasto srityje buvo išmatuotas arterinis kraujospūdis.

Tiriamiesiems gulint ant kairiojo šono, ultragarso aparatu Philips su 3,5 MHz davikliu, suteptu specialiu geliu, dvimatejje erdvejje atlikta standartinè transtorakalinè dvimaté echokardiografija. Pagal Amerikos echokardiografijos asociacijos rekomendacijas M režimu paarasternalinėje ilgojoje ašyje diastolès pabaigoje išmatuoti šie morfometriniai dydžiai: tarpskilvelinès pertvaros storis (TSPd), kairiojo skilvelio diastolinis skersmuo (KSDd), kairiojo skilvelio užpakalinès sienelès storis (KSUSd) (Lai et al., 2006). Kairiojo skilvelio masè apskaičiuota taikant Penn konvencijoje priimtą R. B. Devereux (Lang et al., 2005) formulès korekciją:

$\operatorname{KS}$ masè $(\mathrm{g})=1,04 \times\left[(\mathrm{TSPd}+\mathrm{KSDd}+\mathrm{KSUSd})^{3}-\mathrm{KSDd}^{3}\right]-13,6$

Tiriamieji aparatu Archimed 4220 atliko veloergometrini mègini - taikytas nenutrūkstamas pakopomis kas dvi minutes didinamas fizinis krūvis iki submaksimalaus ŠSD (85\% nuo maksimalaus ŠSD) arba krūvị ribojančių simptomų. Maksimalus ŠSD apskaičiuotas pagal formulę: maksimalus $\breve{S S D}=220-$ amžius.

Veloergometrinio tyrimo metu sinchroniškai kas dvi minutes kiekvienos krūvio pakopos paskutines $10 \mathrm{~s}$ buvo užrašyta EKG ir Korotkovo metodu išmatuotas arterinis kraujospūdis.

12 -13 metų tiriamieji krūvi pradèjo nuo $25 \mathrm{~W}$ galingumo, kas dvi minutes didindami galingumą po $25 \mathrm{~W}$. 14-17 metų sportininkai krūvị pradèjo nuo 50 galingumo, kas dvi minutes didindami galingumą po $50 \mathrm{~W}$. Visi tiriamieji mynè veloergometrą 60 apsukų per minutę dažniu. Veloergometrinio tyrimo metu registruojant funkcinius rodiklius buvo vertinama trijų sistemų - vykdančiosios (veikiančio raumenyno), reguliacinès (apimančios centrinès nervų sistemos, autonomini bei humoralini valdymą) ir aprūpinančiosios (ŠKS) veikla ir sąsajos tarp šių sistemų (Vainoras, 1996). Pradejus tyrimą ir per kiekvieną krūvio pakopą analizuoti šie funkciniai rodikliai: ŠSD (vertintas visose sinchroniškai registruotose EKG derivacijose, skaičiuojant kiekvienos kardiociklų serijos vidurki), R-R intervalas (apskaičiuotas pagal formulę $R R=60$ / ŠSD), intervalas J-T (JT), sistolinis arterinis kraujospūdis (S), diastolinis arterinis kraujospūdis (D), pulsine amplitudè (S-D) ir išvestinis dydis - santykine repoliarizacija JT / RR. J-T intervalo matavimai atlikti II standartinèje derivacijoje, skaičiuojant rankiniu būdu. Funkciniai rodikliai S ir ŠSD yra labiau susiję su reguliacine sistema, S-D — su periferijos raumenų funkcija ir apibūdina vykdančiosios sistemos atsaką, JT nusako aprūpinančiają sistemą, JT / RR rodo reguliacinès ir aprūpinančiosios sistemos sąsajas. Norint ịvertinti fiziologinių rodikliu (ŠSD, JT, JT / RR, S, D, S-D) kitimo krūvio metu kiekybinę vertę, apskaičiuotas jų kitimo greitis kas antrą krūvio minutę, t. y. kiek fiziologiniai rodikliai didejjo vienam krūvio vatui kas antrą fizinio krūvio minute. 
Greitis apskaičiuotas pagal formulę:

$$
\mathbf{f}_{i}=\left(\mathbf{f}\left(\mathbf{N}_{\mathrm{i}+1}\right)-\mathbf{f}\left(\mathbf{N}_{\mathrm{i}}\right)\right) /\left(\mathbf{N}_{\mathrm{i}+1}-\mathbf{N}_{\mathrm{i}}\right)
$$

čia $\mathrm{f}_{\mathrm{i}}$ - fiziologinio rodiklio kitimo greitis krūvio metu; $\mathrm{i}=2,4$, $6,8,10,12$ krūvio minute, kai krūvis didinamas kas 2 minutes; $\mathrm{N}=0,25,50,75,100,125 \mathrm{~W}-12-13$ metu sportininkams ir $\mathrm{N}=0,50,100,150,200,250 \mathrm{~W}-14-17$ metu tiriamiesiems.

Statistinė analizė. Aprašomajai rodikliu analizei atlikti buvo apskaičiuotas parametrų aritmetinis vidurkis, $95 \%$ pasikliautinumo intervalas (PI), standartinis nuokrypis (SN). Tikrinant statistines hipotezes, t. y. kaip normalusis skirstinys atitinka kriterijus, buvo taikomi parametriniai (porinis $t$ testas, vienaveiksmė dispersinė analizė ANOVA, Pirsono tiesinès koreliacijos koeficientas) ar neparametriniai testai (Mann-Whitney, Kruskal-Wallis kriterijai, Spirmeno ranginè koreliacija). Reikšmingumo lygmuo (p), tikrinant statistines hipotezes, pasirinktas $\mathrm{p}<0,05$. Skaičiavimai atlikti naudojant MS Office Excel ir SPSS 15 programų paketus.

\section{TYRIMO REZULTATAI}

Tiriamujų charakteristika pateikta 1 lenteleje. Palyginus ŠSD kitimo greiti nustatyta, kad sportuojančių tiriamujų ŠSD kitimo greitis statistiškai reikšmingai mažesnis už kontrolinès grupès šio rodiklio kitimo greiti $(p<0,05)$. Sportuojančiu tiriamujų šio rodiklio kitimo kreivè yra tolygiai mažejanti. Irkluotojų ŠSD kitimo greitis mažiausias aštuntą, krepšininkų ir dviratininku - dešimta minutę. Kontrolinès grupès tiriamujų ŠSD kitimo greičio kaita savita: šeštą minutę kontrolinès grupès tiriamieji pasiekia mažiausią šio rodiklio kitimo greiti, nuo šeštos - greitis tolygiai padidejja. Statistiškai reikšmingas skirtingų sporto šaku tiriamuju ŠSD kitimo greičio skirtumas išryškejja ketvirtą ir šeštą minutę (1 pav.).

Iš 2 paveiksle pateiktų duomenu matyti, kad fizinio krūvio metu visų tiriamujų JT kitimo greitis fizinio krūvio metu mažèja. Iki fizinio krūvio ketvirtos minutes JT intervalo trukmès kitimo greičiai panašūs visose grupèse. Dviratininkų JT intervalo kitimo greitis nuo šeštos iki aštuntos minutès beveik nekinta, nuo aštuntos minutès mažèja tolygiai. Aštuntą minutę išryškèja skirtumas tarp dviratininkų ir krepšininkų bei irkluotojų rodikliu $(p<0,05)$. Šššą minutę kontrolinès grupès tiriamuju JT kitimo greitis staiga padideja, nuo šeštos iki aštuntos minutès vèl tolygiai mažèja.

Tiriamuju JT / RR kitimo greičio duomenys pateikiami 3 paveiksle. Mažiausias irkluotojų ir dviratininkų JT / RR kitimo greitis nustatytas aštuntą minutę, nuo aštuntos iki dešimtos — padidèja. Išanalizavus kontrolinès grupès tiriamujų JT / RR kitimo greitị nustatyta, kad iki šeštos minutès kontrolinès grupès tiriamujų JT / RR kitimo greitis mažèja tolygiai, šeštą minutę šio rodiklio greitis yra mažiausias, nuo šeštos iki aštuntos - padidèja.

Netolygiausia krepšininkų JT / RR kitimo greičio kreivè: nuo antros iki ketvirtos minutès mažèja, nuo ketvirtos iki šeštos — šiek tiek dideja, nuo šeštos - vèl mažèja, nuo aštuntos iki dešimtos beveik nekinta. JT / RR kitimo greičio skirtumas nustatytas tarp kontrolinès grupès tiriamuju ir sportininku rodiklių $(p<0,05)$. Statistiškai reikšmingo skirtumo tarp skirtingų šakų sportininkų JT / RR kitimo greičio neaptikta.

Tyrimas parodè, kad S kitimo greitis tiriamuju grupèse skirtingas. Iš 4 paveiksle pateiktų duomenų matyti, kad sportuojančių tiriamuju grupèse iki šeštos minutès $\mathrm{S}$ kitimo greičio kaita nedidelè. Nuo šeštos iki dešimtos minutès irkluotoju ir dviratininkų S kitimo greitis tolygiai mažèja, krepšininku — nuo šeštos iki aštuntos minutès mažèja, aštuntą - pasiekia mažiausią reikšmę, nuo aštuntos - padidejja. Išanalizavus $\mathrm{S}$ kitimo greiti sportininku grupése nustatyta, kad ketvirta ir šeštą minutę išryškèja skirtumas tarp irkluotojų ir dviratininku rodikliu $(\mathrm{p}<0,05)$. Kontrolinejje tiriamujų grupejje iki šeštos minutès šio rodiklio kitimo greitis mažèja tolygiai, šeštą minutę yra

\begin{tabular}{|c|c|c|c|c|c|c|c|c|}
\hline Grupè & $\mathbf{N}$ & $\begin{array}{l}\text { Sporto sta- } \\
\text { žas, m. }\end{array}$ & $\begin{array}{c}\text { Amžius, } \\
\text { m. }\end{array}$ & $\overline{\text { Uggis, }} \mathbf{c m}$ & Svoris, kg & \begin{tabular}{|c|} 
Atlikto darbo \\
galingumas, $\mathbf{W}$
\end{tabular} & KSMM* & $\begin{array}{l}1 \text { lentelè. Tiria- } \\
\text { mų grupių cha- } \\
\text { rakteristika }\end{array}$ \\
\hline 1. Krepšininkai & 59 & $4,3 \pm 1,9^{2,3}$ & $\begin{array}{l}14,9 \pm \\
1,4\end{array}$ & $178,9 \pm 11,4^{2,4}$ & $67,1 \pm 14,6^{3}$ & $189,8 \pm 54,2^{4}$ & \begin{tabular}{|l|}
$201,3 \pm$ \\
$68,6^{4}$
\end{tabular} & \\
\hline 2. Irkluotojai & 48 & $\begin{array}{l}2,4 \pm \\
1,4^{1}\end{array}$ & $\begin{array}{l}15,0 \pm \\
1,7\end{array}$ & $176,9 \pm 8,6$ & $65,8 \pm 12,7^{3}$ & $200,0 \pm 55,5^{4}$ & $\begin{array}{l}196,8 \pm \\
49,6^{4}\end{array}$ & \\
\hline 3. Dviratininkai & 53 & $\begin{array}{l}2,7 \pm \\
1,4^{1} \\
\end{array}$ & $\begin{array}{l}14,7 \pm \\
7,4\end{array}$ & $171,9 \pm 9,8^{1}$ & $59,1 \pm 12,2^{1,2}$ & $195,3 \pm 59,1^{4}$ & $\begin{array}{l}196,6 \pm \\
46,2^{4}\end{array}$ & \\
\hline 4. Kontrolinė gr. & 79 & & $\begin{array}{l}14,7 \pm \\
1,6\end{array}$ & $173,9 \pm 17,8^{1}$ & $63,3 \pm 15,6$ & $127,2 \pm 36,3^{1.2,3}$ & $\begin{array}{l}149,3 \pm \\
35,9^{1,2,3}\end{array}$ & \\
\hline
\end{tabular}

Pastaba. Duomenys pateikti: vidurkis $\pm \mathrm{SN}$ (standartinis nuokrypis). Simboliai ${ }^{1,2,3,4}$ lentelès stulpelyje reiškia statistini patikimumą ( $\left.\mathrm{p}<0,05\right)$ tarp atitinkamų grupių rodiklių reikšmių, pvz.: ${ }^{2,4}$ rodo statistinį rodiklio skirtumo patikimumą tarp krepšininkų ir dviratininkų (2 gr.) bei kontrolinès grupès rodiklių (4 gr.); * - kairiojo skilvelio miokardo masė (KSMM). 
1 pav. ŠSD kitimo greičio kaita grupèse krūvio metu

Pastaba. $\mathrm{p}<0,05$ antrą krūvio min $-1: 4$ 2:4, 3:4; ketvirtą min $-1: 3,1: 4,2: 3,2: 4,3: 4$; šeštą min $-1: 2,2: 4,3: 4$; aštuntą min $-1: 4$, $2: 4,3: 4$.

2 pav. JT kitimo greičio kaita grupėse krūvio metu

Pastaba. $\mathrm{p}<0,05$ šeštą krūvio min $-1: 4$, $2: 4,3: 4 ;$ aštuntą min $-1: 3,2: 3$.

3 pav. Santykinio rodiklio JT / RR kitimo greičio kaita krūvio metu
Pastaba. $\mathrm{p}<0,05$ antrą krūvio min $-3: 4$; ketvirtą min $-1: 4$; šeštą min $-1: 4$; aštuntą $\min -3: 4$.
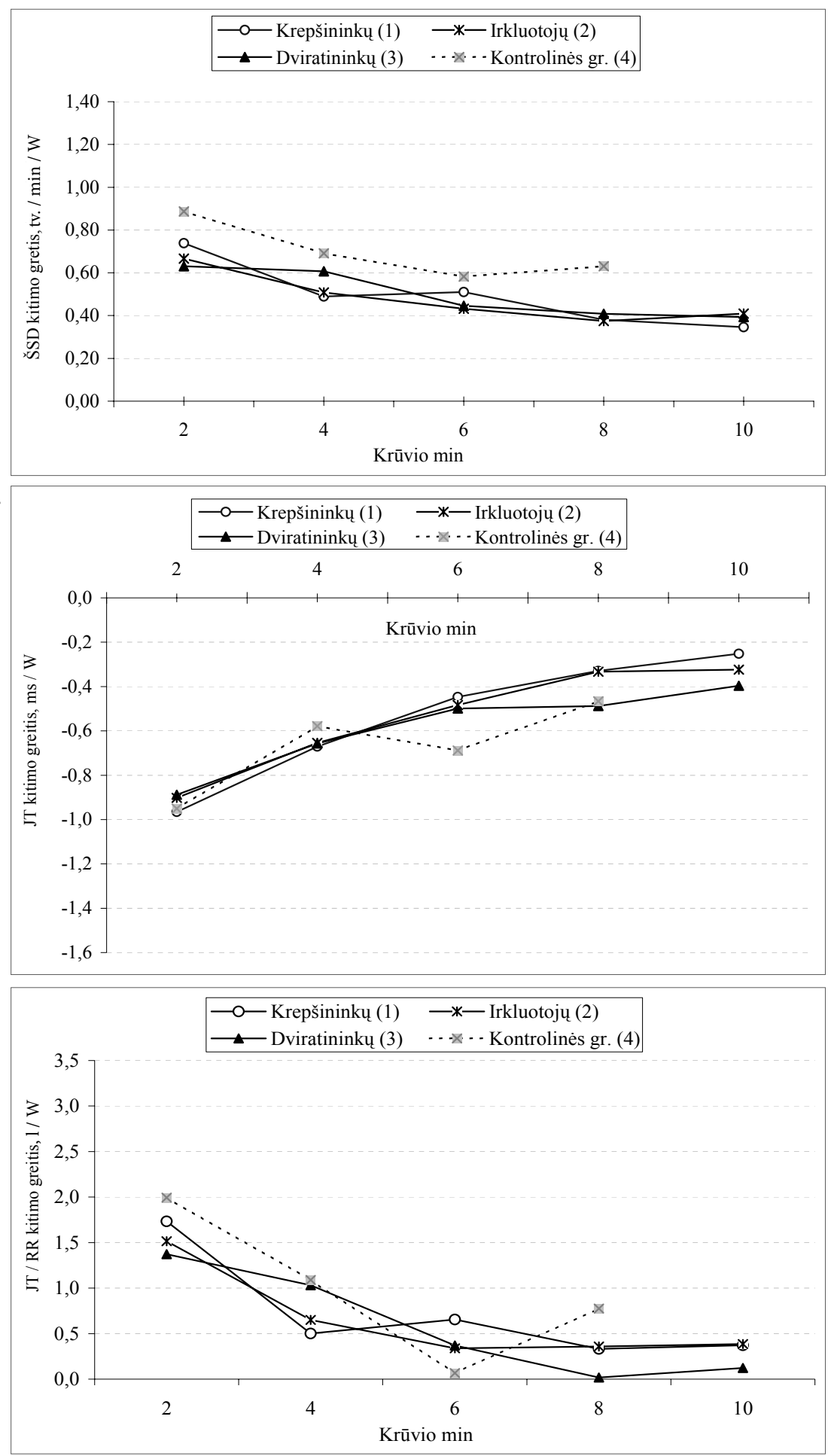

mažiausias, o nuo šeštos iki aštuntos - dideja. Antrą, šeštą ir aštuntą minutę išryškejja statistiškai reikšmingas skirtumas tarp kontrolinès grupès tiriamujų ir sportuojančiujų rodiklių $(\mathrm{p}<0,05)$.

5 paveiksle pateikti (S-D) kitimo greičio duomenys. Nustatyta, kad dviratininku ir irkluotoju (S-D) kitimo greitis panašus: iki šeštos minutès kinta nedaug, nuo šeštos iki dešimtos — tolygiai mažèja. Krepšininkų šio rodiklio greitis iki aštuntos minutès mažèja tolygiai, aštuntą minutę pasiekia mažiausią reikšmę, nuo aštuntos iki dešimtos padidèja. Iki šeštos minutès kontrolinès grupès tiriamuju (S-D) kitimo greitis tolygiai mažeja, šeštą minutę yra mažiausias, nuo šeštos - dideja. Antrą, šeštą ir aštuntą minutę išryškèjo statistiškai reikšmingas (S-D) kitimo greičio skirtumas tarp tiriamuju grupiu $(\mathrm{p}<0,05)$.

Rezultatai parodė KSMM koreliaciją su ŠSD, JT, S kitimo greičiais. Antra, ketvirta ir aštunta fizinio krūvio minutę išryškẻja neigiamas koreliacinis ryšys tarp KSMM ir ŠSD kitimo greičio $(\mathrm{r}=-0,3)$, dešimtą minutę nustatytas stipresnis 

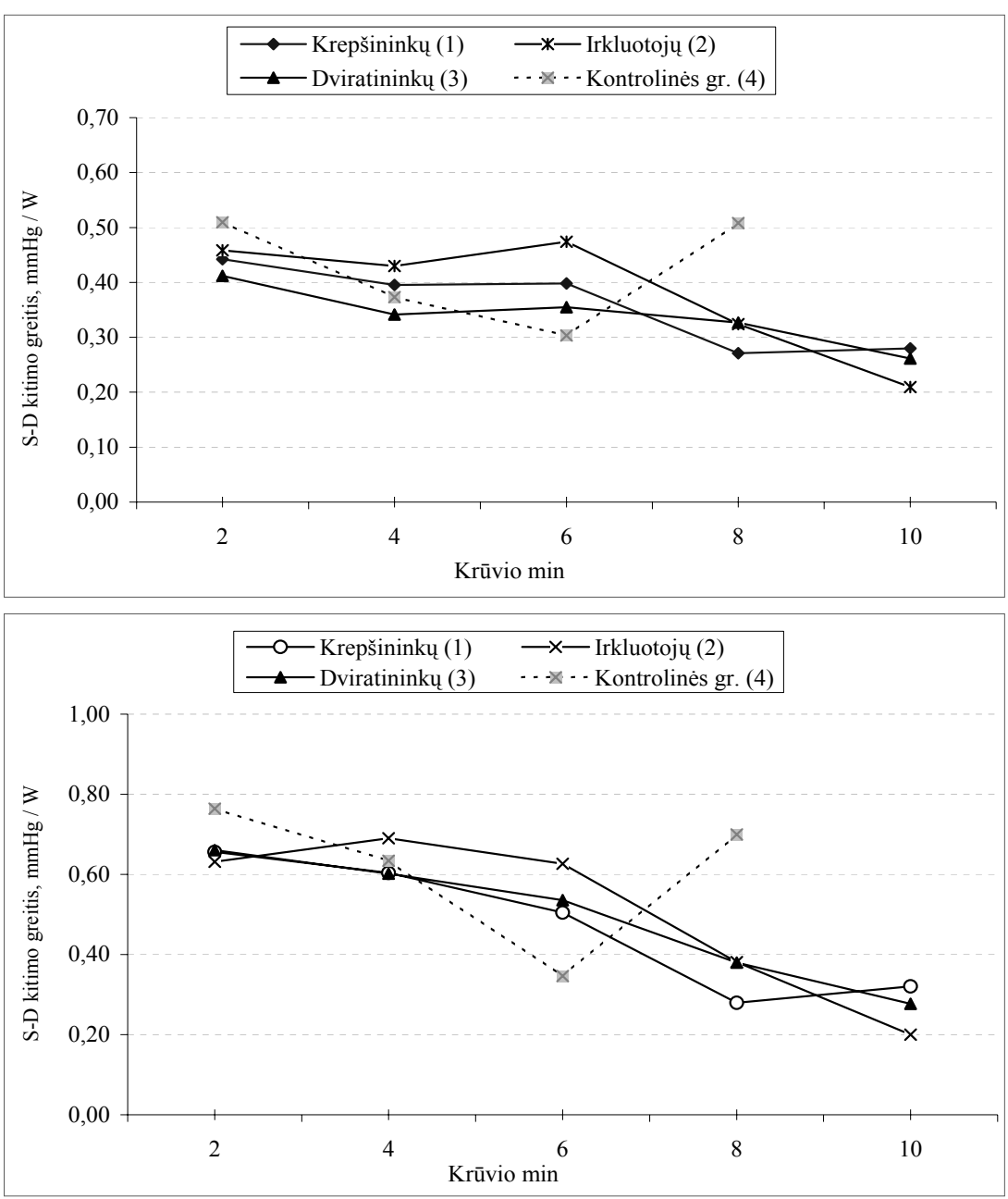

4 pav. S kitimo greičio kaita krūvio metu

Pastaba. $\mathrm{p}<0,05$ antrą krūvio min $-3: 4$; ketvirtą min $-2: 3$; šeštą min $-1: 4,2: 3,2: 4$; aštuntą $\min -1: 4,2: 4,3: 4$

5 pav. Pulsinès AKS amplitudès (S-D) kitimo greičio kaita krūvio metu

Pastaba. $\mathrm{p}<0,05$ antrą krūvio min $-1: 4$, $2: 4$; šeštą min $-1: 2,1: 4,2: 4,3: 4$; aštuntą $\min -1: 4,2: 4,3: 4$ neigiamas koreliacinis ryšys tarp ŠSD kitimo greičio ir KSMM $(r=-0,5)$. Šeštą minutę nustatytas teigiamas koreliacinis ryšys tarp JT kitimo greičio ir KSMM $(r=0,3)$, dešimtą — kiek silpnesnis neigiamas koreliacinis ryšys tarp KSMM ir S kitimo greičio $(\mathrm{r}=-0,2)$.

\section{REZULTATŲ APTARIMAS}

Fizinio krūvio metu atsirandantys organizmo funkcijų pokyčiai - tai ne vienos organizmo sistemos funkcinès būklès kaita, o sudètingų tarpusavyje susijusių daugelio procesų visuma (Biggiero, 2001). Šioje procesu grandineje svarbus vaidmuo tenka ŠKS, kurios funkcinis pajègumas daugiausia lemia organizmo adaptaciją prie fizinio krūvio. Todèl norèdami išsamiau išanalizuoti ilgalaikio fizinio krūvio poveikį sportuojančių vaikų ir paauglių ŠKS, taikème integralios organizmo reakcijos i fizinị krūvị modelị (Vainoras, 1996).

Kintant fizinio krūvio sunkumui iki maksimalaus, keičiasi ir ŠKS funkciniai rodikliai, bet jų analizè neatskleidžia periferinių ir centrinių kraujotakos reguliavimo mechanizmo ryšiu, todèl moksliniais tyrimais pradèti nagrinèti rodiklių kaitos greičiai ir jų tarpusavio ryšiai. Tai padeda giliau suvokti kraujotakos reguliavimo mechanizmus fizinio krūvio metu (Žumbakytè, 2007). Yra žinoma, kad ŠKS funkcinès galimybès dažnai tampa veiksniu, ribojančiu organizmo adaptaciją prie ilgalaikio fizinio krūvio. Tačiau duomenu apie sportuojančiu vaikų ir paaugliu ŠKS funkcinius pokyčius nepakanka. Šiuo tyrimu norèta atsakyti i klausimus, ar vaikų ir paaugliu organizmo adaptacija prie fizinio krūvio skiriasi nuo suaugusių sportininkų, ar sporto šakos pobūdis lemia skirtingas sportuojančių vaikų ir paaugliu funkciniu rodiklių kitimo greičio reakcijas, kaip laiku ịvertinti sportuojančių vaikų ir paaugliu ŠKS funkcinių galimybių ribas bei išvengti sveikatos sutrikimų. Todèl analizuojant tyrimo rezultatus buvo įvertinti ŠKS rodiklių kaitos greičiai ir ju tarpusavio ryšiai.

Svarbiu širdies ir kraujagyslių sistemos adaptacijos galimybių rodikliu laikoma ŠSD kaita (Darr et al., 1988). Augant vaikui, 10-15 gyvenimo metais, kol dar neišsivyste kraujotakos perskirstymo mechanizmas, dideja širdies darbingumas fizinio krūvio metu, ir čia pagrindinis vaidmuo tenka ŠSD (Turley, Wilmore, 1997; Žemaitytè, 1997; Winsley et al., 2003). Vertinant funkcinių rodiklių kitimo 
greiti pastebėta, kad sportininkų ŠSD kitimo greitis statistiškai patikimai mažesnis už kontrolinès grupès tiriamujų atitinkamą rodiklị ir fizinio krūvio metu tolygiai mažèja. Šio tyrimo duomenys patvirtina literatūros duomenis, rodančius, kad ilgalaikis organizmo adaptavimasis prie fiziniu krūvių didina parasimpatinès nervų sistemos aktyvumą ir kartu mažina širdies susitraukimų dažnị. Akivaizdu, kad mažesnis sportuojančiu tiriamuju ŠSD kitimo greitis rodo geresnę adaptaciją prie fizinio krūvio. Tai tvirtina ir kiti autoriai, tyrę suaugusius sportininkus (Žumbakytè, 2007).

Širdies metaboliniai pokyčiai yra susiję su JT intervalu (Vainoras, 1996). Fizinio krūvio metu sportuojančiu JT intervalo kitimo greitis yra mažesnis už nesportuojančių (Žumbakytè, 2007). Atlikto tyrimo rezultatai iš dalies tai patvirtina. Sportuojančiu tiriamujų JT intervalo kitimo greitis tolygiai mažèja ir šeštą fizinio krūvio minutę pasidaro statistiškai patikimai mažesnis už nesportuojančių tiriamujų. Tai rodo geresnę sportuojančių ŠKS adaptaciją prie fizinio krūvio.

Organizmo širdies ir kraujagyslių sistemos funkcijos mobilizacijos dydi gerai nusako elektrokardiogramos JT ir RR intervalu santykis JT / RR (Vainoras, 1996; Vainoras ir kt., 1999). Atliktas tyrimas parode, kad mažiausią JT / RR kitimo greitị sportininkai pasiekia aštuntą minutę, kontrolinès grupès tiriamieji — šeštą minutę, vèliau greitis padidejja. JT / RR kitimo greičio padidejjimas per paskutinę krūvio pakopą rodo tiriamujų funkciniu galimybių ribą ir rezerviniu galimybių mobilizaciją. Kai kurie autoriai teigia, kad pagal ši rodikli galima būtų nustatyti, kada būtina riboti fizini krūvị (Žumbakytè, 2007).

Suaugusių asmenų sistolinio kraujospūdžio pokyčiai fizinio krūvio metu svarbūs nustatant širdies ir kraujagysliu sistemos funkcines galimybes, organizmo persitreniravimo arba persitempimo procesus (Kelley et al., 1999). Mokslininkai, tyrę suaugusius sportininkus, teigia, kad sportininku S kitimo greitis nuo pat fizinio krūvio pradžios didèja (Žumbakytè, 2007). Tai rodo ryškesni suaugusių sportininku reguliacinès sistemos atsaką i fizini krūvị. $\mathrm{Au}-$ toriai, tyrinejję vaikų ir paaugliu ŠKS adaptaciją prie fizinio krūvio, tvirtina: tik pasibaigus vaikų ir paaugliu brandai ir galutinai susiformavus kraujo srovès perskirstymo fizinio krūvio metu mechanizmui, pokyčius fizinio krūvio metu lemia sistolinio kraujospūdžio kaita (Focht, Koltyn, 1999). Atlikto tyrimo rezultatai patvirtino ši teiginị: sportininku S kitimo greitis iki šeštos krūvio minutès beveik nekito, nuo šeštos - tolygiai mažèjo.
Sportininkų pulsinès amplitudès (S-D) greičio kaitos didesnè amplitudè, lyginant su nesportuojančiujų, rodo intensyvesni vykdančiosios sistemos (raumenyno) ỉsitraukimą ị fizini krūvi (Žumbakyté, 2007). Tai patvirtina ir mūsu gauti duomenys. Akivaizdu, kad nesportuojančių tiriamujų vykdančioji sistema nèra adaptuota prie tokio krūvio ir ju rezervinès galimybès išsenka anksčiau, lyginant su sportininku.

Per paskutines fizinio krūvio pakopas galima nustatyti tiriamuju širdies raumens darbingumo ribą ir kompensacinių mechanizmu įsitraukimo procesus (Vainoras, 1996; Poderys, 2004). Palyginus sportininkų ir kontrolinès grupès tiriamujų funkcinių rodiklių kitimo greičio kreives nustatyta, kad sportininkų JT / RR, S, (S-D) greitis maksimaliai sumažèja aštuntą minutę, o kontrolinès grupès tiriamuju — šeštą. Vèliau šiu rodikliu kitimo greitis tiriamuju grupese padideja. Tai rodo geresnę sportininkų adaptaciją prie fizinio krūvio. Antra vertus, šie rezultatai leidžia daryti prielaida, kad fizinio krūvio metu sportininkams pasiekus rezervinių galimybių mobilizacijos stadija gali būti viršijamos ŠKS funkcinių galimybių ribos. I tai svarbu atsižvelgti ir laiku ịvertinti sportuojančiu vaiku ir paaugliu persitreniravimą, kitas būsenas, sukeliančias grèsmę jų organizmui, bei parinkti optimalius fizinius krūvius.

Lyginant rodiklius tiriamuju grupèse pagal sporto šakas nustatyta, kad krepšininkų mažiausias $\mathrm{S}$, (S-D) kitimo greitis yra aštuntą minutę, o kitų sportininkų - dešimtą. Be to, netolygiausia JT / RR greičio kitimo kreivè nustatyta tarp krepšininkų. Tai rodo didesni reguliacinès ir aprūpinančiosios sistemos îsitraukimą i fizinị krūvị ir nepakankamą vykdančiosios sistemos adaptaciją prie fizinio krūvio. Kitokius duomenis pateikia R. Žumbakytè. Mokslininkè nustatè, kad krepšininkų širdies ir kraujagyslių sistemos adaptacija prie fizinio krūvio geresne, lyginant su kitų šakų sportininkais. Panašiai teigia ir kiti tyrejjai (Vasiliauskas ir kt., 2006). Atlikto tyrimo duomenys leidžia daryti prielaida, kad kintamo intensyvumo aciklinis krepšinio sporto šakos pobūdis ir ilgesnè treniravimosi trukmé, lyginant su kitomis, lemia tokius krepšininkų rodiklius. O gal ši skirtumą iš dalies galejo lemti sportinio krūvio intensyvumas ir trenerio parinkta treniruotès strategija? Vis dèlto ši teigini būtina patikrinti ištyrus didesni krepšininkų kontingentą.

Mokslineje literatūroje aptinkama duomenų, irodančių, kad sportininkų kairiojo skilvelio miokardo mases (KSMM) rodikliai koreliuoja su ŠSD ir sistoliniu kraujospūdžiu (S) (Malcolm et al., 1993; Graetinger et al., 1995; Cubero et al., 2000). Atlik- 
tas tyrimas tai patvirtino. Nustatytas neigiamas koreliacinis ryšys tarp sportininkų ŠSD kitimo greičio ir KSMM jau antrą fizinio krūvio minutę. Didejjant fizinio krūvio galingumui, koreliacinis ryšys stiprèjo. Maksimalaus fizinio krūvio metu, t. y. dešimtą minute, nustatytas silpnas teigiamas $\mathrm{S}$ kitimo greičio ir KSMM koreliacinis ryšys. Šį reiškinį galima paaiškinti taip: dèl fizinio krūvio persimodeliuoja KS. Ši pokytị rodo padidèjęs KS sienelių storis, KS skersmuo ir KSMM. Todèl galingesnis KS miokardas lemia geresnę sportininko širdies ir kraujagysliu sistemos adaptaciją prie fizinio krūvio.

Taigi tyrimas parodè, kad sportuojančių ir nesportuojančių tiriamuju nagrinètų širdies ir kraujagyslių sistemos rodikliu kitimo greitis skirtingas. Veloergometrinio krūvio metu registruojamų rodiklių kitimo greičio pokyčiai leidžia tiksliau įvertinti širdies ir kraujagyslių sistemos funkcinę būklę.

\section{IŠVADOS}

1. Sportuojančių vaikų ir paauglių ŠSD kitimo greitis statistiškai reikšmingai skiriasi nuo nesportuojančių tiriamujų atitinkamo rodiklio.

2. Sportuojančiu vaikų ir paauglių ŠSD, JT / RR, $\mathrm{S}$, (S-D) kitimo greitis mažiausias aštuntą fizinio krūvio minutę, nesportuojančių tiriamųjų - šeštą.

3. JT / RR greičio amplitudè labiau kinta krepšininku, lyginant su irkluotojų, dviratininku ir nesportuojančių tiriamujų rodikliais.

4. Fizinio krūvio pradžioje nustatytas sportuojančių tiriamuju KSMM ir ŠSD kitimo greičio neigiamas koreliacinis ryšys, kuris stiprejo didinant fizinị krūvị.

\section{LITERATŪRA}

Amstrong, N., Welsman, J. (2005). Physiology of the child athlete. Lancet, 366 (1), 44-45.

Biggiero, L. (2001). Sourus of complexity in human systems. Journal of Nonlinear Dynamics. Psychology and Life Sciences.

Bartkevičienė, A., Bakšienė, D. (2007). Sportuojančių vaiku ir paauglių širdies morfometriniu parametrų pokyčiai ir kairiojo skilvelio funkcija. Medicina, 43 (3), 251-258.

Cubero, G. I., Batalla, A., Reguero, J. J. R. et al. (2000). Left ventricular mass index and sports: The influence of different sports activities and arterial blood pressure. International Journal of Cardiology, 75, 261-265.

Darr, K. C., Basset, D. R., Morgan, B. J., Thomas, D. P. (1988). Effects of age and training status on heart rate recovery after peak exercise. American Journal of Physiology, 254, 340-343.

Emeljanovas, A., Venskaitytè, E., Danusevičiūtè, L., Poderys, J. (2006). Reguliarių sportinių žaidimų ir ciklinių sporto šaku pratimu poveikis $11-14$ metų berniukų raumenų bei širdies ir kraujagyslių sistemoms. Ugdymas. Küno kultūra. Sportas, 3 (62), 3-10.

Focht, B. C., Koltyn, K. F. (1999). Ifluence of resistance exercise of different intensities on state anxiety and blood pressure. Medicine and Science in Sports and Exercise, 31, $456-463$.

Graetinger, W. F., Smith, D. H., Neutel, J. M. et al. (1995). Relationship of ventricular structure to maximal heart rate during exercise. Chest, 107 (2), 341-345.

Kelley, G. A. (1999). Aerobic exercise and resting blood pressure among women: A meta-analysis. Preventive Medicine, 28 (3), 264-275.

Lai, W., Geva, T., Shirali, G. et al. (2006). Guidelines and Standards for Performance of a Pediatric Echocardiogram: A Report from the Task Force of the Pediatric Council of the American Society of Echocardiography. Journal of the American Society of Echocardiography, 19 (12), 1413-1430.

Lang, R. M., Bierig, M., Devereux, R. B. et al. (2005). Recommendations for chamber quantification: A report from the American Society of Echocardiography's Guidelines and Standards Committee and the Chamber Quantification Writing Group, developed in conjunction with the European Association of Echocardiography, a branch of the European Society of Cardiology. Journal of American Society of Echocardiography, 18, 1440-1463.

Lodish, H., Berk, A., Zipursky, S. L. et al. (2000). Molecular Cell Biology. New York.

Malcolm, D. D., Burns, T. L., Mahoney, L. T., Lauer, R. M. (1993). Left ventricular mass and exercise responses predict future blood pressure. The Muscatine Study Pediatrics, 92 (5), 703-709.

Poderys, J. (2004). Kineziologijos pagrindai: mokomoji knyga. Kaunas.

Poškaitis, V., Miseckaitė, B., Venskaitytè, E., Poderys, J., Vainoras, A. (2007). Deguonies isotinimo raumenyse ir funkcinių išeminių reiškinių miokarde kitimo ypatybès atliekant pakopomis didejjantị krūvị veloergometru. Medicina, 43 (5), 385.

Sharma, S. (2003). Athlete's heart - effect of age, sex, ethnicity and sporting discipline. Experimental Physiology, 88 (5), 665-669.

Spirito, P., Pelliccia, A., Proschan, M. A. et al. (1994). Morphology of the "athlete's heart" assessed by echocardiography in 947 elite athletes representing 27 sports. The American Journal of Cardiology, 74 (8), 802-806.

Triposkiadis, F., Ghiokas, S., Skoularigis, I. et al. (2002). Cardiac adaptation to intensive training in prepubertal swimmers. European Journal of Clinical Investigation, 32 (1), 16-23.

Turley, K. R., Wilmore, J. H. (1997). Cardiovascular responses to treadmill and cycle ergometer exercise in children and adults. Journal of Applied Physiology Exercise and Muscle, 83 (3), 948-957.

Vainoras, A., Gargasas, L., Jaruševičius, G. et al. (1999). Veloergometrija ir sisteminių vertinimu galimybè. Lithuanian Journal of Cardiology, 6 (2), 760-762.

Vainoras, A. (1996). Širdies repoliarizacijos procesu tyrimas ramybès ir fizinio krūvio metu (100-taškès ir iprastinès 
EKG duomenys): habilitacinis darbas. Kaunas: KMU. Vasiliauskas, D., Venckūnas, T., Marcinkeviciene, J., Bartkeviciene, A. (2006). Development of structural cardiac adaptation in basketball players. European Journal of Cardiovascular Prevention and Rehabilitation, 13, 985-989. Winsley, R. J., Armstrong, N., Bywater, K., Fawkner, S. G. (2003). Reliability of heart rate variability measures at rest and during light exercise in children. British Journal of Sports Medicine, 37 (6), 550-552.

Žemaitytė, D. (1997). Širdies ritmo autonominis reguliavimas: mechanizmai, vertinimai, klinikine reikšmè. Palanga.

Žumbakytè, R. (2007). Krepšininku ir futbolininku funkcinès būkless ypatybès naudojant integraliojo vertinimo modeli: daktaro disertacija. Kaunas: KMU.

\title{
ASSESSMENT OF FUNCTIONAL PARAMETERS OF CARDIOVASCULAR SYSTEM IN CHILDREN AND ADOLESCENT ATHLETES
}

\author{
Aldona Bartkevičiene் $\dot{1}^{1}$, Alfonsas Vainoras ${ }^{2}$, Dalia Bakšiené ${ }^{2}$ Julija Brožaitiené ${ }^{1}$, \\ Nijolė Raškauskiene் ${ }^{1}$, Sigita Kibildiené $\dot{~}^{3}$, Nadežda Rožnova ${ }^{4}$ \\ Institute of Psychophysiology and Rehabilitation clo Kaunas University of Medicine ${ }^{l}$, Palanga, Kaunas University of \\ Medicine ${ }^{2}$,Kaunas, Klaipėda Sports Medical Centre ${ }^{3}$, Klaipèda, Klaipéda Children Hospital ${ }^{4}$ Klaipèda, Lithuania
}

\begin{abstract}
There is a strong need for more studies to analyze the adaptive changes of cardiovascular system to exercise training in children and adolescent athletes.

The aim of the research was to describe alternations in the speed of changes in the parameters of cardiovascular system during exercise test in $12-17$ years old athletes.

The sample consisted of 160 male basketball players, rowers and cyclists between 12 and 17 years and healthy 79 non- athlete controls of similar age and the same gender.

All the subjects were examined by M-mode and 2-dimensional echocardiography. Left ventricular enddiastolic internal diameter, posterior wall thickness, as well interventricular wall thickness were measured from M-mode echocardiography. Left ventricular mass (LVM) was calculated.

All the participants of the study performed a graded exercise test on cycle ergometer. 12 ECG standard derivations were synchronically recorded every other minute. The following functional parameters and the speed of their changes were estimated: heart rate (HR), JT interval, RR interval, systolic blood pressure(S), diastolic blood pressure (D), pulse blood pressure amplitude (S-D), JT / RR ratio.

The results showed that speed of changes in HR of athletes during all the stages of the exercise test was lower than that in the control group $(\mathrm{p}<0.05)$. Differences in the speed of changes in HR, JT, JT / RR, S and (S-D) between athletes and controls have been reported in the last stages of the exercise test. The lowest speed of changes in HR observed in rowers in the 8-th min, in basketball players and cyclists - in the 10-th min, and in controls - in the 6-th min of the exercise test. We found statistically significantly higher speed of changes in JT in controls than that of athletes in the 6-th min of the exercise $(\mathrm{p}<0.05)$. The lowest speed of changes in JT / RR observed in athletes in the 8-th min (the difference between the cyclists and the controls $\mathrm{p}<0.05$ ), in controls - in the 6-th min (the difference between the basketball players and the controls $p<0.05$ ). Basketball players showed the lowest speed of changes in S and (S-D) in the 8 th min (the difference between the basketball players and the controls $\mathrm{p}<0.05$ ), cyclists and rowers - in the 10-th min, controls - in the 6-th min of the exercise test (the difference between the rowers, the basketball players, the cyclists and the controls $\mathrm{p}<0.05)$, After reaching the lowest values, the speed of changes in HR, JT / RR, S, (S-D) increased in athletes and controls. The dynamic of speed changes in JT / RR ratio in basketball players is peculiar, compared to those of cyclists and rowers. The speed of changes in HR correlated significantly in athletes to LVM at the beginning of the load $(r=-0,3)$. Stronger correlation between the speed of changes in HR and LVM was found in the 10-th min of the exercise test $(r=-0,5)$.

These findings showed that the athletes have reached the lowest values of speed of changes in the parameters in the final stages of the exercise test later compared to controls, and that suggests a better adaptation of cardiovascular system to physical exercise. Nevertheless, the alternation of speed of changes in JT / RR, S and (SD) in the final steps of the exercise can indicate the limit of functional possibilities of cardiovascular system.
\end{abstract}

Keywords: cardiovascular system, speed of changes in functional parameters, left ventricular mass.

Gauta 2008 m. gegužès $1 \mathrm{~d}$.

Received on May 1, 2008

Priimta $2008 \mathrm{~m}$. birželio $18 \mathrm{~d}$.

Accepted on June 18, 2008
Aldona Bartkevičienè

Kauno medicinos universiteto Psichofiziologijos ir reabilitacijos institutas

(Institute of Psychophysiology and Rehabilitation c/o Kaunas University of Medicine)

Vydūno al. 4, LT-00135 Palanga

Lietuva (Lithuania)

Tel +37046484156

E-mail abartkeviciene@hotmail.com 